\title{
American Indians at Wounded Knee in Current U.S. History High School Textbooks: Discourse Analysis Using the APPRAISAL JUDGMENT System
}

\author{
Michael W. Simpson J.D., M.Ed \\ University of Arizona
}

American Indians and allies have provided checklists and guidelines for the evaluation of textbooks for a long time. Henry (1970) called for accurate descriptions of American Indians peoples and the causes of conflicts. Others have asked that we look for stereotypes, loaded words, and distortion of history (Slapin, Searle, \& Gonzalez , 1992). The Council on Interracial Books for Children examined high school history texts in 1977 and reported on key points missed and continuing problems with inclusions regarding American Indians. These and other such sources have been valuable in contesting much of what was identified in 1885 by the Superintendent of Indian Schools who complained about the mainstream textbooks that alternatively represented Indians as monsters and as romantic heroes (Reyhner \& Eder, 2004, p. 75). Rarely, in my review of textbooks do I find the explicit language found in my paper on late $19^{\text {th }}$ century school textbooks (Simpson, 2006). However, as a teacher in American Indian schools, my students and I really questioned any improvement. History still felt like a weapon. This paper is the result of the search to find a method or approach to help teachers and students learn about how historical discourse in school textbooks requires history to be thought about in certain ways. The search led me to Australia and the work specifically of Carolyn Coffin. She was part of a group that researched literacy in Australia and that developed the APPRAISAL System which was informed by Halladay's Systemic Functional Literacy (SFL)(Coffin, 1996; Martin \& White, 2005, p. xi; Coffin, 2006, xiii). Wodak and Meyer (2009) note Halladay as the theoretical attractor for Fairclough's wellknown Dialectical-Relational approach to critical discourse analysis (CDA)(pp. 20, 27). Coffin compares her definition of discourse with Fairclough's and confirms their similarity in that discourse is meaning-making as part of a social process that examines the relationship between meaning and social and cultural contexts (2006, p. 11). Any difference is found in Coffin's more linguistic focus at least within the APPRAISAL system while Fairclough begins with language as just one semiotic meaning maker but a very important one (1995, pp. 187-8). An additional difference is that Fairclough seeks to right a social wrong as an explicit social justice goal while Coffin seeks to improve literacy without assuming a social wrong. Coffin does recognize that her analysis increases awareness of embedded ideology defined as a way of understanding the world as opposed to false or distorted consciousness ( $\mathrm{p}$. 41). Power differential is examined by understanding different rhetorical strategies, positioning, and examination of schooling in shaping subjectivities (pp. 42-3). I would argue that Coffin's examination of historical discourse using the APPRAISAL system is a form of CDA. Her analysis sees language as a social phenomena and looks beyond the clause. This distinguishes discourse analysis from CDA (Wodak \& Meyer, 2009, p. 2). Coffin examines real texts rather than made up abstractions. This is also an important part of CDA (p. 14; Wodak \& Meyer, p. 2). 
This paper examines one small part of an actual high school historical textbook concerning the 1890 events at Wounded Knee. Our introduction is limited to one aspect of the APPRAISAL system: JUDGMENT. Before we focus on this one aspect, a tour of the entire system is useful in contextualizing the JUDGMENT focus.

SFL asserts that language occurs in social context (instance perspective) and that writers make choices among many words to effect meaning (system perspective)(Coffin, 2006, pp. 18-19, 25). The social context has three variables collectively referred to as the register (p. 29). The register has a field which is the topic of the social activity, a mode which is the role of language and degree of interactivity, and a tenor which involves social relations of status and solidarity or role structure or who is taking part. Tenor is the part of register of most interest for JUDGMENT because it focuses the interpersonal function of language (p. 41). The APPRAISAL system of analysis is concerned with the interpersonal meaning making. APPRAISAL maps the resources available to give value to a social experience ( $\mathrm{p}$. 141).

The system looks at resources in the areas of engagement, graduation, and attitude (Appendix 1, Coffin, 2006, p. 142). Engagement draws upon Bakhtin's concept of heteroglossia and authoritative discourse (Coffin, 2006, p. 143; Martin \& White, 2005, pp. 102-04). Monogloss engagement assumes sharing the same, singular world view. Positive declaration encourages the reader to assume the proposition is unproblematic. Heterogloss uses modal resources that indicate meaning is contingent or negotiable (e.g. may, probably). Another important resource for hetergloss is to quote or report statements as made by others (Coffin, p. 144; Martin \& White, pp. 98, 111-117). At times, this attribution becomes important in JUDGMENT as well.

Graduation refers to the force and the focus of the textual resources used. Some resources make a statement stronger or more forceful while others weaken. Other resources mark very specific statements while others are vaguer (Coffin, 2006, p. 153; Martin \& White, 2005, p. 37).

Three groups of resources exist within the attitude section of APPRAISAL resources (Coffin, 2006, p. 141). Affect resources have to do with emotions. Affect explains how events make us feel. Appreciation resources are concerned with the aesthetics or social valuing of things or social processes (Martin \& White, 2005, p. 42-3). JUDGMENT resources involve ethics (p. 42). JUDGMENT, like affect and appreciation, deals with feelings and like appreciation deals with institutionalized feelings. But unlike either affect or appreciation, JUDGMENT deals with attitudes toward behavior (Coffin, p. 141). All of these attitudinal resources tend toward prosodic realization. This means that meaning arises throughout a stretch of discourse and that parts effect the whole; each choice works with other choices to establish a tone or mood (Martin \& Rose, 2007, pp. 25, 59). This concept is especially important to remember when we start an actual JUDGMENT assessment and especially in regards to non-explicit expressions of JUDGMENT.

JUDGMENT deals with resources that express feelings about ethical behavior. These resources can be further classified into those involving social esteem and those involving social sanction (Martin \& White, 2005, p. 52). Social esteem is seen as involving criticism or admiration without possible legal sanctions. Social sanction is more likely to involve moral and legal rules made explicit by a culture (Coffin, 2006, p. 146). 
The questions asked within social esteem and social sanctions provide the application framework for JUDGMENT analysis. Under social esteem, we look at normality or how behavior or way of life is unusual (Martin \& White, 2005, p. 52). For capacity or competence, we look to feelings of capability. And for tenacity or resolve, we look for evaluation of how dependable, committed, or disposed the subject is. Under social sanction, we look for veracity or truthfulness and ask how honest the subject is. In addition, we look toward propriety or ethics and ask if the subject is beyond reproach.

The chart attached provides a list of explicit descriptions found in actual historical discourse (Appendix 2, Martin \& White, 2005, p. 53). This chart is useful to refer while reading text. The user must understand that the list of words is neither complete nor intended as a dictionary of values, but intended to provide a sense of the particular JUDGMENT (p.52). Remember that JUDGMENT can be explicit or evoked (Martin \& Rose, 2007, pp. 33-4) . Recall that meaning may be evoked from the APPRAISAL choices throughout of the text (p. 25). Certainly, when the specific words are used, we would want to consider them as explicit realizations. Otherwise, we can consider the words in a broader way as a sense of what might be evoked. Evoked realizations are called Tokens of Judgment (Coffin, 2006, p. 147).

Now that we have the system lay out, we can talk about notation and consider a couple of examples (Coffin, 1997, p. 207).

"This period of black resistance in Sydney finally ended in 1816. It is a significant period in Australian history as it showed the determination of the Aboriginal people to resist the invasion." (bold added)

The above excerpt is an example of direct or explicit realization of JUDGMENT. The bolded section provides a positive statement of the tenacity of Aboriginal peoples. This would be noted as $(+$, tenacity of Aboriginal peoples). Determination and resistance are direct realizations of tenacity.

Now consider the following example of evoked or indirect realization (Coffin, 2006, p. 147).

\section{"When the Europeans arrived in 1788 they occupied sacred land and destroyed Eora hunting and fishing grounds..."}

Occupying and destroying are not expressions of JUDGMENT. However, taking over the sacred lands of another and destroying their ability to live free on the land does evoke severe ethical implications. The integrity or propriety of European actions is evaluated by not only words in the phrase but by the social and cultural context. This text can be noted as ( $\mathrm{T}$, - integrity or propriety of Europeans). The Token of Judgment is indicated by $\mathrm{T}$.

Before analyzing a sample text, consider a summary of the examination process:

1. Is the judgment direct (explicit) or indirect (evoked) realization? T notes Token of Judgment or evoked realization.

2. Does the judgment relate to social esteem (normality, capacity, tenacity) or social sanction (veracity, propriety or ethics)?

3. Is the evaluation positive or negative and to whom is evaluated?

Below is the actual text from Boyer's The American Nation (2001).

p. 438 "Wounded Knee. Frightened and angry after Sitting Bull's death, many Sioux joined the Ghost Dancers farther west. Some 
traveled with Big Foot, a Sioux leader who had initially supported the Ghost Dance but had gradually turned away from it. Government officials wanted to arrest Big Foot because they feared he might cause trouble. Hoping to avoid conflict with army troops, Big Foot decided to lead his group to the Pine Ridge Reservation. On December 28, 1890, army troops found Big Foot and some 350 members of his group. The Sioux made camp for the night along Wounded Knee Creek.

The next morning, Colonel James Forsyth of the $7^{\text {th }}$ Cavalry ordered the removal of Indian rifles. Reinforced by four Hotchkiss guns that fired exploding shells, some 500 mounted soldiers surrounded the camp. When the Sioux surrendered only a few guns, soldiers began to search the teepees. Tensions ran high. Nerves snapped, and the Sioux and U.S. soldiers began shooting. The Hotchkiss guns ripped into the camp. By day's end some 300 Sioux and about 30 U.S. soldiers had been killed. Some people declared that Custer and the $7^{\text {th }}$ Cavalry had been "avenged," but the Massacre at Wounded Knee shocked many Americans. The incident marked the end of the bloody conflict between soldiers and American Indians on the Great Plains."

Here is my analysis:

p. 438 "Wounded Knee. (1)Frightened and angry after Sitting Bull's death, many Sioux joined the Ghost Dancers farther west. Some traveled with Big Foot, a Sioux leader who had initially supported the Ghost Dance but had gradually turned away from it. Government officials wanted to arrest Big Foot because (2)they feared he might cause trouble. Hoping to avoid conflict with army troops, Big Foot decided to lead his group to the Pine Ridge Reservation. On December 28, 1890, army troops found Big Foot and some 350 members of his group. The Sioux made camp for the night along Wounded Knee Creek. The next morning, Colonel James Forsyth of the $7^{\text {th }}$ Cavalry ordered the removal of Indian rifles. (3)Reinforced by four Hotchkiss guns that fired exploding shells, some 500 mounted soldiers surrounded the camp. (4) When the Sioux surrendered only a few guns, soldiers began to search the teepees. Tensions ran high. Nerves snapped, and the Sioux and U.S. soldiers began shooting. The Hotchkiss guns ripped into the camp. By day's end some 300 Sioux and about 30 U.S. soldiers had been killed. (5)Some people declared that Custer and the $7^{\text {th }}$ Cavalry had been "avenged," but the (6) Massacre at Wounded Knee shocked many Americans. The incident marked the end of the bloody conflict between soldiers and American Indians on the Great Plains." (bold are part of original text; underlines added) 
(1) $\mathrm{T}$ - normality (by being frightened and angry, the Sioux appear outside normal state of being)

(2)T -veracity (by fearing Big Foot would cause trouble, they were essentially saying that he was dishonest and deceitful)

(3) T + capacity (U.S. troops had capability to destroy)

(4)T - veracity (by surrendering only a few guns makes Lakota appear dishonest, deceitful)

(5)T + propriety (good to avenge the defeat at Little Big Horn). But note use of "Some people."

(6)T - propriety (Massacre of Natives by government bad; shocked conscience ). However, note "many Americans."

Through the use of "some people" and "many Americans", the writer appears to be fair and simply reporting the split among Americans (which apparently means only citizens of the U.S or those nonIndian peoples). This makes the entire account appear nothing less than an objective heteroglossic rendering of the facts.

Analysis summary: The Sioux are judged negatively three times and never positively. The government is judged three times, two positively and once negatively. But as discussed above the negative is hedged by attribution and heteroglossic rendering. As such the Sioux are negatively judged in the total scheme while the government is seen as a powerful force that reasonable people could differ on the judgment of their actions. The entire passage is forgrounded by the Sioux as in a state of agitation.

The above analysis is not THE analysis. The JUDGMENT framework is highly determined by cultural and ideological values and individual experiences (Coffin, 2002, p. 521; Appraisal website, 2005). People may classify different behaviors differently. While most academic application has used a Western world view, I encourage teachers in American Indian schools to use the framework to teach English vocabulary and ideology and then to compare and contrast with the particular native nation's words and world view. The JUDGMENT word list attached could be redeveloped from the actual descriptions of American Indians in textbooks over time. By teaching this issue, students are made aware that how they see things depends to a large extent on who they are and the way writers position the reader is determined by who the author is and who the author imagines the reader to be. Martin \& White note the importance of declaring variables such as gender and class when analyzing (2005, p. 62).

This allows instruction on the developing voice theory that has emerged from APPRAISAL. Voice theory is a descriptive tool that explores how interpersonal styles have become conventionalized (Coffin, 2002, p. 519). Coffin shows different voices in school history writing and connects with JUDGMENT. The particular voice is influenced by the social purpose, the genre, and the degree of perceived solidarity and alignment with imagined reader (p. 520). Coffin identifies three common voices in school history writing: recorder, interpreter, and adjudicator. Recorder voice is very common with complete absence of explicit JUDGMENT. Interpreter voice is not likely to use inscribed social sanction and will moderately use inscribed social esteem. Adjudicator uses both social esteem and social sanction freely in direct and invoked ways.

In our example analysis, the JUDGMENTs identified were all tokens. This is consistent with the recorder voice (Coffin, 2002, p. 517). In recorder voice, alternative perspectives are generally absent. While the author shows disagreement among people about the Wounded Knee events, such seems 
consistent with a recorder voice here in that the voice seems to be simply reporting factually that people disagreed rather than inviting a detailed analysis into differing perspectives. This is especially true if readers investigate the event in detail with other sources and see what has been left out. The recorder voice assumes reader alignment with the author's world views. No one is surprised about the prevalence of this voice in school history texts.

Here is another passage to evaluate (Danzer, 2009, pp. 413-14):

The Sioux continued to suffer poverty and disease. In desperation, they turned to Paiute prophet who promised that if the Sioux performed a ritual called the Ghost Dance, Native American lands and way of life would be restored.

The Ghost Dance movement spread rapidly among the 25,000 Sioux on the Dakota reservation. Alarmed military leaders ordered the arrest of Sitting Bull. In December 1890, about 40 Native American police were sent to arrest him. Sitting Bull's friend and bodyguard, Catch-the-Bear, shot one of them. The police then killed Sitting Bull. In the aftermath, Chief Big Foot led the fearful Sioux away.

Wounded Knee. On December 28, 1890, the Seventh Cavalry Custer's old regiment - rounded up about 350 starving and freezing Sioux and took them to a camp at Wounded Knee in South Dakota. The next day, the soldiers demanded that the Native Americans give up all their weapons. A shot was fired; from which side, it was not clear. The soldiers opened fire with deadly cannon.

Within minutes, the Seventh Cavalry slaughtered as many as 300 mostly unarmed Native Americans, including several children. The soldiers left the corpses to freeze on the ground. This event, the Battle of Wounded Knee, brought the Indian wars - and an entire era - to a bitter end.

Potential analysis:

(1) The Sioux continued to suffer poverty and disease. (2)In desperation, they turned to Paiute prophet who promised that if the Sioux performed a ritual called the Ghost Dance, Native American lands and way of life would be restored.

The (3) Ghost Dance movement spread rapidly among the 25,000 Sioux on the Dakota reservation. Alarmed military leaders ordered the arrest of Sitting Bull. In December 1890, about 40 Native American police were sent to arrest him. Sitting Bull's friend and bodyguard, Catch-theBear, shot one of them. The police then killed Sitting Bull. In the aftermath, Chief Big Foot led the (4)fearful Sioux away.

Wounded Knee. On December 28, 1890, the Seventh Cavalry Custer's old regiment - (5)rounded up about 350 starving and freezing 
Sioux and took them to a camp at Wounded Knee in South Dakota. The next day, the soldiers demanded that the Native Americans give up all their weapons. A shot was fired; from which side, it was not clear. The (6) soldiers opened fire with deadly cannon. (7)Within minutes, the Seventh Cavalry slaughtered as many as 300 mostly unarmed Native Americans, including several children. (8) The soldiers left the corpses to freeze on the ground. This event, the Battle of Wounded Knee, brought the Indian wars - and an entire era - to a (9) bitter end.

(1) T- capacity (Sioux are poor and diseased; no indication of cause outside of Sioux)

(2) $\mathrm{T}$ - normality (Sioux desperate)

(3) T-capacity (Sioux just accept Ghost Dance without thought, spread throughout as if no agency)

(4) T - normality, tenacity (fearful Sioux might be in a state of not following orders, resisting)

(5) T- capacity(Sioux simply rounded up like animals, no resistance)

(6) $\mathrm{T}+$ capacity (Soldiers have great capability to kill)

(7) T-propriety (Soldiers slaughtered some unarmed people and children, the use of slaughtering continues the Sioux as animal theme, "mostly unarmed" provides some justification for actions and the context places soldier actions within context of an unknown source of a shot and the fearful Sioux); T - capacity (Sioux slaughtered meant not an effective resistance)

(8) T-propriety (soldiers left corpses to freeze on ground, violates idea of good Christian burial, decency)

(9) T + propriety (sadly but necessarily, the government ended the Indian wars--victory in this battle was "bitter" but unavoidable)

\section{Analysis summary}

The Sioux are judged negatively six times. The Sioux are presented as a poor, sick, and angry group with guns they are unwilling to give up. The Sioux as something less than human is advanced by terms such as being rounded up, slaughtered and lacking agency and capacity to think. The causes of their poverty and disease is not discussed nor the reasonable stance of not giving up guns when the great leader Sitting Bull had been killed in a government attempt to arrest him. The killing of women is not mentioned. The government or soldiers are presented with great capacity such as killing all in minutes which misstates the evidence that soldiers killed many Sioux miles from the site and that the chase lasted for hours. The government's negative is tempered by the larger context in the passage and the theme that killing Indians in this way was very sad, but inevitable and necessary for progress. Thus, the racist idea of Manifest Destiny is restated. Voice: once again we see a strong recorder voice. Any judgments are invoked. This voice would be consistent with the massage given that the sick and poor Sioux sadly needed to be killed so the Indian wars would end. 
Great similarity is seen in the textual descriptions of the same historical event in the two textbooks. The recorder voice makes the text appear to be merely an objective statement of what really happened. However, invoked judgment is negative for the Sioux and mostly positive for the government. Negatives against the government are reduces by attribution or by the larger context and both accounts continue the manifest destiny theme that justified genocide. Further critical analysis can lead to insight about why the texts are so similar.

This paper has introduced the APPRAISAL system broadly and demonstrated the JUDGMENT subsystem by examining an excerpt from an actual U.S. history textbook concerning Wounded Knee. This system can assist in the critical examination of historical discourse and show students various resources available to them in writing history. Critical examination is encouraged especially in regard to American Indians who continued to be slandered by the historian's pen (O'Connell, 1992, p. 61). This

is only a part of a broader critical discourse study, but I argue it is useful and takes us further into a meaningful analysis beyond mere checklists and guidelines.

\section{References}

Appraisal website. (2005) Retrieved November 17, 2009, from http://grammatics.com/Appraisal/ Boyer, P. (2001). Boyer's the American nation. Austin, TX: Holt, Rinehart, and Winston.

Coffin,C. (1996). Exploring literacy in school history. Sydney: Disadvantaged Schools Program, Metropolitan East Region.

Coffin, C. (1997). Constructing and giving value to the past: An investigation into secondary school history. In F. Christie \& J.R. Martin (Eds.), Genre and institutions: Social processes in the workplace and school (pp. 196-230). London: Continuum.

Coffin, C. (2002). The Voices of History: theorising the interpersonal semantics of historical discourses. Text, 22(4), pp. 503-528.

Coffin, C. (2006). Historical discourse: The language of time, cause and evaluation. London: Continuum.

Danzer, G. et.al. (2009). The Americans. Evanston, IL: McDougal Little.

Fairclough, N. (1995). Critical discourse analysis: The critical study of language. Harlow, England: Pearson Education

Henry, J. (1970). Textbooks and the American Indian. (R. Costo, Ed.). San Francisco: The Indian Historian Press.

Martin, J.R., \& Rose, D. (2007). Working with discourse: Meaning beyond the clause (2d ed.). London: Continuum.

Martin, J.R., \& White, P.R.R. (2005). The language of evaluation: Appraisal in English (2d ed.). New York: Palgrave Macmillan.

O'Connell, B. (Ed.)(1992). On our own ground: The complete writings of William Apess, a Pequot. Amherst, MA: University of Massachusetts Press.

Reyhner, J., \& Eder, J. (2006). American Indian education: A history. Norman, OK: University of Oklahoma Press.

Slapin, B., Searle, D., \& Gonzalez, R. (1992). How to tell the difference: A checklist for evaluating children's books for anti-Indian bias. Philadelphia: New Society. 
Simpson, M. (2006, April). Teach your children well: A critical examination of the genuine historyof late $19^{\text {th }}$ century school textbooks. Available on the Conference Literature page of the Office of Indian Education. Retrieved October 27, 2009, from:

http://www.ed.gov/rschstat/research/pubs/oieresearch/conference/simpson_200604.doc

Wodak, R. \& Meyer, M. (Eds.) (2009). Methods of critical discourse analysis (2d ed.). Los Angeles: Sage. 